\title{
CULTURAL PARADIGM AND POPULAR CANON THE DISCOURSE ON NATION IN NINETEENTH- CENTURY MUSIC OF SLAVIC MITTELEUROPA
}

\author{
IVANO CAVALLINI \\ Università di Palermo
}

Izvleček: Nacionalna identiteta slovanske Srednje Evrope je v razpravi obravnavana z novim pristopom $k$ različnim kulturnim paradigmam, takim, ki upošteva zgodovinske dogodke, preko katerih se je ob koncu 18. stoletja na Poljskem in v 19. stoletju na Čě̌kem, Slovenskem in na Hrvaškem uveljavil splošno priznani glasbeni kanon. Pojav kanona je treba analizirati vokviru, $v$ katerem sta kozmopolitizem in nacionalizem soobstajala $v$ prepletu uporabne in avtonomne glasbe, kar presega zamejevanje v kategorije podrejenosti, prirejenosti in avtonomije.

Ključne besede: paradigma, glasbeni kanon, 19. stoletje, slovanska Srednja Evropa.

\begin{abstract}
The national identity of Slavic Mitteleuropa is examined by means of a new approach to different cultural paradigms, namely the historical events out of which the popular canon in music flourished at the end of eighteenth-century Poland and in nineteenth-century Bohemia, Slovenia and Croatia. This phenomenon must be analysed within a framework in which cosmopolitism and nationalism co-existed in a mix of functional and autonomous music, superseding the boundaries of subordination, adaptation and autonomy.
\end{abstract}

Keywords: paradigm, musical canon, nineteenth century, Slavic Mitteleuropa.

\section{Central Europe as Geographic Space, Mitteleuropa as Cultural Space}

It may seem a contradiction to speak of music as one of the development factors in the identity processes of the Slavic countries of Central Europe, and at the same time to refer to Mitteleuropa as a place for the cohabitation of cultures and of reciprocal tolerance. But in actual fact this is not so, provided that we precisely trace the boundaries that contain the concepts of national identity, Central Europe and Mitteleuropa. These are three preliminary concepts that need to be clarified before we proceed to deal with the music.

First. The countries I wish to discuss briefly are Poland, Bohemia, Slovenia and Croatia. In the nineteenth century these countries were constrained between the political influences of Prussia, Russia and Austria (then Austria-Hungary from 1867). On the one hand, they set up Czech-Polish Pan-Slavism as a measure to counteract those dominations and as an alternative to the Russian Pan-Slavism, which had imperialistic connotations, resulting from the creation of state nationalism by Tsars Aleksandr I and Nikolaj I Romanov - an 
"official nationalism" as Hugh Seton-Watson called it. ${ }^{1}$ On the other hand, the Croatian Illyrian movement and its successors prepared the project for a country of the southern Slavs, to which the Slovenes (after the phase of the Illyrian Movement, ca. 1835 - 1848) adhered in order to preserve their independence, since in neither language nor culture could they be said to be similar to the people of Bosnia, Serbia and Montenegro.

Second. The terms Central Europe and Mitteleuropa need to be used with caution. Regarding merely the geographical aspects, Central Europe corresponds to a territorial area comprising the countries situated between the Alps and the North and Baltic Seas, with an important appendix in the Mediterranean between Trieste and Rijeka, as well as the regions lying between Alsace and Poland (I omit the intricate question of the Baltic Ring and Ukraine). The concept of Mitteleuropa, on the other hand, developed from a series of political objectives that flourished in the period bridging the nineteenth and twentieth-centuries, and it referred to the union of the peoples in a bipartite federation governed by Austria and Germany. To this was added the tripartite solution, advocated by the Austro-Slavic movement, which aimed to mitigate the power of the crowns of Austria and Hungary through an active participation of the Slavic peoples. ${ }^{2}$ Although these proposals were never realized, they nonetheless had a secondary effect that should not be overlooked, for it was the political culture associated with them that provoked the downfall of the dynastic universalism of the Habsburgs, who were reluctant to concede more independence. The next steps were first the clash between the national groups and Austria and then the fatal disagreement among the new states at the time of the partition of the empire in $1919 .{ }^{3}$

Third. In a climate dominated by fear of the Irredentisms and the expansionist ambitions of Germany, it is not surprising that the intellectuals expressed their most heartfelt petitions just before the Great War. With the onset of the Fascisms these entreaties became more acute after 1920, and increased their appeal with the separation of Europe into two blocks in 1945. Some writers, during the years of the Iron Curtain, not only harked back to the defunct K.u.K. monarchy, which they judged to be better than the dictatorships, but also acknowledged, with a touch of nostalgia, the common traits of the peoples disseminated over the lands of Central Europe, whatever their language. ${ }^{4}$

For the reasons outlined here, the idea of Mitteleuropa is unthinkable without the contribution of those who advocated the freedom of states within the framework of a new federation. If the struggle for national autonomies within the framework of a united Europe is rejected, the result is a severe distortion of history. ${ }^{5}$ The adoption of an antinationalist

1 Seton-Watson, Nations and States: An Enquiry into the Origins of Nations, 148; Anderson, Imagined Communities, 83-113.

2 Vodopivec, "Mitteleuropa-Mythos oder wirklichkeit?", 29-42.

3 Bibó, Misère des petits États d'Europe de l'Est, 133-139. This work dates back to 1946 and contains excellent intuitions, in spite of the theoretical limitations dictated by the period in which it was written.

4 Magris, Il mito asburgico nella letteratura austriaca moderna; Le Rider, Mitteleuropa, 85-96.

5 Agnelli, La genesi dell'idea di Mitteleuropa, 59: "The idea of Mitteleuropa acquires its own meaning in relationship to the concept of nation [...] and not if the dynastic universalism is opposed to it." 
position, which developed around the 1960s, can be explained by the serious situation that was generated by the provisions of Versailles and became exacerbated in the period from the end of World War II right up until the fall of the Berlin Wall. In this respect a revealing episode is described in the autobiography of Dragotin Cvetko, the father of Slovenian musicology, and is supported by further statements made to me during personal meetings in Trieste and Ljubljana between 1985 and 1991.

In 1937, after acquiring a grant from Czechoslovakia thanks to the intercession of the minister Kamil Kroft, young Cvetko, a student who had specialized in composition in Prague, found himself in an excellent position to observe the looming Nazi threat. ${ }^{6}$ In order to understand the German and Slovak claims that threatened the unity of the young republic, Cvetko, acting as correspondent for the newspaper Jutro, went to Moravia, the Sudetenland and then to Bratislava; and from there he continued his survey journey to the Subcarpathian area. It was then that he, as a cosmopolitan and a democrat hostile to the authoritarian regime of the first Yugoslavia, understood that the advocates of revanchism were still unaware of the ferocity of Hitler's Nazism. As a result the German-speaking citizens acclaimed the Führer for his defence of their nationality and independence. On this subject Cvetko gained valuable insights by meeting Mihajlo Rostohar, an eminent psychologist at the University of Brno. Rostohar explained to him that within such extreme nationalism lay the roots of fascism and the negation of all ethnic otherness. This was an Innatist theory that Cvetko had only sensed, though he later witnessed its tragic consequences first in Vienna, where the Jews were reduced to slavery, and then with the violent Italian and German occupation of his own country (1941-1945). ${ }^{7}$ From the Slovene Rostohar we know that it was impossible to engage in a peaceful debate on nationalisms. And it would have been even harder to outline an objective classification founded on the intricate web of different kinds of nationality: democratic, linguistic, biological, political, cultural and general (i.e. evolutionary-annexionist towards minorities). ${ }^{8}$

In other respects, the article by Milan Kundera on the post-1945 central-European catastrophe, "La tragédie de l'Europe central", is still relevant. ${ }^{9}$ Published in English by the New York Review of Books, ${ }^{10}$ the article denounced the brutal elimination of a geographical entity that had been a vivid expression of the Western identity for centuries. Nevertheless, still today many musicologists insist on continuing to call this part of the continent Eastern Europe, considering it as a peripheral area. As a result, writes Kundera, the border moved hundreds of kilometres westwards, whereby the states that were geographically at the centre found themselves in the East, and the peoples whose civilizations belonged to the West suddenly became citizens of the East:

Geographic Europe (extending from the Atlantic to the Ural Mountains) was always divided into two halves which evolved separately: one tied to ancient Rome and the Catholic Church, the other anchored in Byzantium and the Orthodox Church. After

6 Cvetko, V prostoru in času, 38-39.

7 Ibid., 45-52.

8 Symaniec, La construction idéologique slave orientale, 51-56.

9 Kundera, "Un occident kidnappé ou la tragédie de l'Europe centrale", 3-23.

${ }^{10}$ Id., "The Tragedy of Central Europe", 33-38. 
1945, the border between the two Europes shifted several hundred kilometers to the west, and several nations that had always considered themselves to be Western woke up to discover that they were now in the East. As a result, three fundamental situations developed in Europe after the war: that of Western Europe, that of Eastern Europe, and, most complicated, that of the part of Europe situated geographically in the center culturally in the West and politically in the East. ${ }^{11}$

Contributing to this distorted picture were the errors committed by the Czechs, who flaunted their 'Slavness' by claiming a brotherhood with the Russians, when in actual fact Russia and Bohemia shared neither a history, nor a religion, nor even a culture. The fact of belonging to the same language family was adopted as an argument to resist the advance of the aggressive Pan-Germanism, but at the same time it was also the source of a mystification that permitted the Soviet Union to incorporate the Slavophone states, in addition to Romania and Hungary. This had been an aspiration already cultivated by the Tsars, the roots of which are to be found in the theory of Aleksandr Šškov. Šiškov promoted an anachronistic language family tree, according to which the Russian language boasts a close kinship with Proto-Slavic (viewed as the langue souche). He conferred the primacy on his own "Slavonic dialect" and launched a purging of foreign influences. Conversely, for him the "Carniolan" of the Slovenes, bastardized with the German of the Austrians, had degenerated to the level of a dialect. ${ }^{12}$ In this regard Kundera reiterates an accusation already expressed, though in different words, by Karel Havliček Borovský, as well as by prominent figures such as Mickiewicz, Michelet and Mazzini; an idea that can be summarized by the simple slogan: "slaviser pour russianiser":

I feel that the error made by Central Europe was owing to what I call the 'ideology of the Slavic world'. I say 'ideology' advisedly, for it is only a piece of political mystification invented in the nineteenth century. The Czechs [...] loved to brandish naively their 'Slavic ideology' as a defense against German aggressiveness. The Russians, on the other hand, enjoyed making use of it to justify their own imperial ambitions. 'The Russians like to label everything Russian as Slavic, so that later they can label everything Slavic as Russian', the great Czech writer Karel Havliček declared in 1844, trying to warn his compatriots against their silly and ignorant enthusiasm for Russia. It was ignorant because the Czechs, for a thousand years, have never had any direct contact with Russia. In spite of their linguistic kinship, the Czechs and the Russians have never shared a common world: neither a common history nor a common culture. The relationship between the Poles and the Russians, though, has never been anything less than a struggle of life and death. ${ }^{13}$

While the rebirth of the idea of Mitteleuropa was above all a literary myth encouraged after the downfall of the Empire, it has now been superseded by the creation of the European Union. Nonetheless, the spirit of 'Austrianness' has by no means been eclipsed, since the people of Central Europe live together on the strength of their acceptance of

\footnotetext{
11 Ibid., 34.

${ }^{12}$ Symaniec, La construction idéologique slave orientale, 86-90.

${ }^{13}$ Kundera, "The Tragedy of Central Europe", 38.
} 
similar values that originated in the past and are rooted in the present. What remains an open question, however, is how to examine what connects and divides the identity pathways of the Slavic peoples in relation to music, as well as the problematic acquisition of the dominant German culture.

Even though the contribution of each culture is related to the use of folk canons (and in this sense we can detect profound differences), one must also remember that there were two sources from which the musicians of Mitteleuropa drew from the end of the eighteenth century onwards. The first was the Classical-Romantic movement and the second was the highly professional teaching work carried out by the Czechs, who wielded a considerable influence on the art music and music for entertainment in Poland, Slovenia and Croatia. From the end of that century a large number of patriots and musicians from Bohemia spread throughout the Habsburg Empire, and also in Italy and Germany. In addition to the Mannheimer, the earliest signs of this compact migration can be seen in the imposing presence of Czechs at the court orchestra in Warsaw at the time of Stanisław August Poniatowki. ${ }^{14}$ Shortly before the revolutions of 1848 the Czechs exported the besedy, i.e. the meetings of patriots during which national anthems, Lieder and poems were exhibited. Convened at regular intervals, these meetings were hosted in reading rooms that were called čitalnice by Slovenes and ćitaonice by Croats. During the following fifty years it was the Czechs that occupied the positions of responsibility in the chapels of the Eastern Adriatic coastal centres, both those of Italian and Croatian majority, like Koper and Split respectively. In Ljubljana the violin school was refounded by professionals from Bohemia; ${ }^{15}$ the leading figure in Croatian national opera, Ivan von Zajc from Rijeka, was of Czech origin; the Czech and Slovak bourgeoisie, which flourished in Trieste, owing to the city's status as a free port, was closely associated with the Slovenian institutions; and the first to disseminate the modern piano teaching methods in Trieste was Adolf Skolek, again a Bohemian schooled in Vienna. ${ }^{16}$ An emblematic moment, which took place in 1868, was the reunion of representatives of all the Slavic peoples for the laying of the foundation stone of the National Theatre (Národní Divadlo) in Prague. In spite of the scant participation of Poles and Russians, owing to obvious political disagreements, many were the guests invited from several lands to deliver speeches in their own languages. The národni obrozeni, the project of a Czech revival, became a celebrated model during the period in which Bedřich Smetana ordered the translation of foreign operas for the Provisional Theatre (Prozatímní Divadlo), before the building of the National Theatre. In Zagreb, for the opening of the Croatian National Theatre (Narodno Hrvatsko Kazalište), the management turned to Prague for consultancy, and for the production of Lohengrin the materials were purchased in Prague, not in Bayreuth! The same happened in Ljubljana. On the basis of a linguistic affinity, in spite of the vicinity of Trieste, Venice and Vienna, the Italian, French and German operas were subjected to the same treatment. Lucia di Lammermoor,

${ }^{14}$ Żórawska-Witkowska, "Bömischer Musiker in Warschau unter der Regierung von Stanislaus August Poniatowki (1764-1795)", 242-257.

${ }^{15}$ Zupančič, "V iskanju lastne identitete: češki violinist kot glavni tvorci violinizma na Slovenskem", 105-132; Weiss, Češki glasbeniki v 19. in na začetku 20. stoletja na Slovenskem.

${ }^{16}$ Radole, Le scuole musicali a Trieste e il Conservatorio "Giuseppe Tartini”, 106-107. 
Rigoletto, Il trovatore, La muta dei portici, Carmen and Der fliegende Holländer were all sung in Slovenian rhythmic translations, with scenarios and librettos borrowed from the Národní Divadlo. ${ }^{17}$ At the same time, however, the desire to erect barriers could not prevent the spontaneous interaction between the German and Slavic cultures: they grew together and they influenced one another, even if the scores aiming to emphasize the separate identities constitute the increasing trend.

\section{Paradigm and Canon}

To return to the main assumption of this article - i.e. to establish the causes that led to the discovery of national traditions and to folk music - it is helpful to clarify the concept of paradigm referred to in the title of this paper.

In the field of the exact sciences a paradigm can be summarized as a simple theoretical formulation to which empirical proofs are associated. Given that in cultural matters there are no events that admit universal laws, any act can become a paradigm, even when the subject is 'belonging to a nation'. In this context the paradigm is a concept acquired by historiography as a basis for comparison, since it stimulates change in social dynamics and gives them a different mapping. In the arts, music included, it can be identified as an element of the past that is relevant to the history of a country. The paradigm is subjected to the artifices of revision for reasons that are different from those that can be identified in its position within the narrative, in so far as it is loaded with unpredictable values. In short, the paradigm is a conflictual agent that provokes the reorganization of a constituted order. Its importance, as an element that triggers the construction of concepts of people and nation, has by now been established through the works of Ernest Gellner, Benedict Anderson and Eric Hobsbawm, just to mention only some of the many scholars that have studied the formation of nation states and their respective mythographies. ${ }^{18}$ Even leaving aside the exemplary cases that led to the idea of invented nations, or to the more apposite idea of imagined communities, the paradigm is a process of hypostasization that aspires to become a category, in so far as it is immovable despite the phenomenal flow. This does not exclude stratifications with other factors in the course of time, but the paradigm maintains its privileged position when one acknowledges its prime role in impressing the initial impulse, even if that occurs in unforeseen ways (and here a little irony in the vein of Jean Cocteau would not be out of place: "La source désapprouve presque toujours l'itinéraire du fleuve", Le coq et l'arlequin).

A canon, on the other hand, is an ambiguous regulating principle. It is an instrument of identity that takes the form of a large-scale unifying topos. An example could be folksong: a genre in which ethical references to language, faith and culture are brought together and duly emphasized. These features assume the physiognomy of an exclusive heritage that is irreproducible elsewhere and forcibly confined within the specific context of the nation.

17 Ther, "The Czechs as Cultural Role Models", 49-61.

${ }^{18}$ Gellner, Nations and Nationalism; Anderson, Imagined Communities; Hobsbawm, Nations and Nationalism since 1780. 
In the cases under examination here, the idea of paradigm corresponds to the events that overthrew a pre-existing regime and drove the subordinate groups to identify the canon - i.e. a non-negotiable pattern of self-representation - in an image of the people. In the nineteenth century, for the conquest of an independent state, the people were set up as the ethnic and cultural symbol of the nation. Yet the problem to be solved does not concern the painstaking description of the demotic repertoires so much as the definition of the paradigms from which the folk canon stems.

A scientific paradigm is considered by Thomas Kuhn to be an element that provokes the readjustment of a previous order. On this is based the patient work carried out by Michel Foucault in Les mots et les choses of 1966, a volume published in English with the more explicit title The Order of Things: An Archaeology of the Human Sciences. ${ }^{19}$ In his equally celebrated L'archeologie du savoir of 1969, the philosopher highlights the passages that determine the "thresholds of epistemologization", which correspond to discursive practices before they become science or world vision. ${ }^{20}$ Here we are dealing with a series of experiences out of which alternative meanings emerge, to the extent that one can speak of a before and after. ${ }^{21}$ This means that historical research, if given an anthropological slant, should assume the task of revealing the turn where those values are still burdened by a vocabulary belonging to the old system and where the words needed to

${ }^{19}$ Foucault, Les mots et les choses. Une archéologie des sciences humaines.

${ }^{20}$ Id., The Archaeology of Knowledge and the Discourse on Language, 190: "The third type of historical analysis takes as its point of attack the threshold of epistemologization - the point of cleavage between discursive formations defined by their positivity and epistemological figures that are not necessarily all sciences (and which may never, in fact, succeed in becoming sciences). At this level, scientificity does not serve as a norm: in this archaeological history, what one is trying to uncover are discursive practices in so far as they give rise to a corpus of knowledge, in so far as they assume the status and role of a science. To undertake a history of the sciences at this level is not to describe discursive formations without regard to epistemological structures; it is to show how the establishment of a science, and perhaps its transition to formalization, have come about in a discursive formation, and in modifications to its positivity".

${ }^{21}$ Foucault, The Order of Things: An Archaeology of the Human Sciences, 49: "Discontinuity - the fact that within the space of a few years a culture sometimes ceases to think as it had been thinking up till then and begins to think other things in a new way - probably begins with an erosion from outside, from that space which is, for thought, on the other side, but in which it has never ceased to think from the very beginning. Ultimately, the problem that presents itself is that of the relations between thought and culture: how is it that thought has a place in the space of the world, that it has its origin there, and that it never ceases, in this place or that, to begin a new?"; 366: "Archaeology, then, has two tasks with regard to these figures: to determine the manner in which they are arranged in the episteme in which they have their roots; and to show, also, in what respect their configuration is radically different from that of the sciences in the strict sense."; 368: "the imaginative values then assumed by the past, the whole lyrical halo that surrounded the consciousness of history at that period, the lively curiosity shown for documents or for traces left behind by time - all this is a surface expression of the simple fact that man found himself emptied of history, but that he was already beginning to recover in the depths of his own being, and among all the things that were still capable of reflecting his image (the others have fallen silent and folded back upon themselves, a historicity linked essentially to man himself)." 
give a complete definition of the new concepts have not yet emerged. Or rather, as Giorgio Agamben argues, the paradigm observes the idea of a factor positioned at Degree Zero.

Inspired by Foucault, Agamben takes his cue from Feuerbach's Entwiklungsfähigkeit and in his Signatura rerum he asserts that "the genuinely philosophical element in any work, be it a work of art, one of science, or one of thought, is its capacity for being developed". ${ }^{22}$ He also deals with critical thresholds or signaturae that reveal the advent of a paradigm. But over and above such assertions made by a philosopher, how can the term paradigm be used in historiography? If observed at the instant in which it appears, the paradigm is similar to the bi-stable figures that can be viewed in two different ways (like the white vase or two black faces in Rubin's vase). ${ }^{23}$ Since such images cannot be hybridized, they are an effective metaphor of the paradigm before it assumes a precise aspect by proceeding in one direction rather than in the other. While the paradigm can cloak itself in duplicity during the initial phase, it will subsequently acquire a single meaning, failing which it loses its function as a basis for comparison. A practical reference for the people and the nation is useful.

It is known that such epoch-making concepts are very changeable over the course of time. The lemma Volk, which is linked to the term Volkslied coined by Herder, was subjected to an immediate, though farfetched, double meaning, given that it could refer in certain moments to the idea of people and in others to the idea of nation. For Herder the Volk was identified with the people, who, as depositaries of a historical memory ignored by the élites, were the custodians of the true national sentiment (Volkstum). But if we look more closely, the matter is more complicated. After the Napoleonic campaigns, in fact, many were the German intellectuals who used the notion of the people to refer to the peasant classes and bourgeoisie, excluding the nobility and clergy for moral reasons. ${ }^{24} \mathrm{At}$ its beginning, therefore, the paradigm was expressed in words that are used to designate both the new and the preceding situation. This is an inescapable condition in cultural processes. The words of the past are bearers of an otherness, the deciphering of which will become satisfactory with the adoption of a vocabulary appropriate to the scenario repainted ex post. In this regard Aristotle's statement is always pertinent: "Names are finite and so is the sum total of formulae, while things are infinite in number. Inevitably, then, the same formula, and a single name, have a number of meanings." ${ }^{25}$

In my opinion the paradigm in history has closer analogies with the work of art. Agamben, harking back to the words of Kant, writes that the aesthetic judgement, in cases for which a rule cannot be given, is founded on common sense, and not on logic. In the paradigm there can be no archè; it aspires to archetypicity, it follows an itinerary

\footnotetext{
${ }^{22}$ Agamben, Signatura rerum. Sul metodo, 8.

${ }^{23}$ Fortuna, "Note su oblio, paradigma e discipline linguistiche a partire da Signatura rerum", 205-222.

${ }^{24}$ Cesa, "Popolo, nazione e stato nel romanticismo tedesco", 150-151; Kindl, "Im namen des deutschen Volkes", 321.

${ }^{25}$ Aristotle, De sophisticis elenchis, I, 165, a 11.
} 
in which synchrony and diachrony intersect, and it remains recognisable in spite of the work of readjustment to which it must be subjected. ${ }^{26}$

Obviously history, unlike science, is a subject that cannot boast long-term laws, and it is plagued by discontinuities. From a chronological point of view the paradigms are often contemporaneous, but also alien to one another. In spite of geographical and temporal distances, they can provoke shared reactions, like those occurring within the ideological framework of the national awakening inspired by the people. And in fact the canon originating from these paradigms is the same (i.e. the people). What changes is its morphology, as one can deduce from the musics that, with a great deal of imagination, were called folk music. In any case the relationship between paradigm and canon is causative, never dialectic, so the latter can be born from the former, but it cannot have any influence on the former, given that the former is an a priori that generates the phenomenon. Citing Agamben we could say that the paradigm does not act metonymically; it is a prerequisite for a set of rules, but at the same time it is not a rule.

Another logical consideration, relating to the connection established between paradigm and canon, also deserves close attention. If we take the case of an event external to the arts, for example the Napoleonic campaigns which provided Russia with a valid motive for developing a populism that previously did not exist, should the paradigm emerge in some episode related to music? Or if that should happen, would there be a paradoxical superimposition? I believe that paradigm and canon coexist in a single entity up until the moment when the canon achieves the status of self-sufficient 'pattern'. At the start their position is only virtually separable, since the paradigm cannot restrict itself to external causality, in other words without evident links to what it gives its first impulse to. On the contrary, in order to exhibit its driving force it must anticipate an immediate effect, otherwise it relinquishes its status as epiphany. The paradigm is not a regulatory or prescriptive a quo, but it can be identified historically if it triggers long-lasting effects that give it evidence. The canon, on the other hand, is a regulatory artefact subject to variability, failing which it ceases to have any referential value. It is, potentially, a quid in a working progress, provided that it is recognised as having a persuasive force, even when the paradigm fades into rhetoric.

\section{Emphasis: authentic or invented traditions?}

At this stage we must necessarily tackle the problem of the paradigms in the context of the civil and political transformations involving the Slavic peoples of Mitteleuropa, with the specific aim of illustrating the thresholds of access that led to folk song being indicated as a distinctive sign of the nation. I will limit myself, therefore, to the events that permitted the constitution of the canon, adding some notes on the musics related to it.

The multiplicity of paradigms makes it impossible to trace a uniform portrayal on the web of fragile similarities, since their identification is suggested by concrete situations. Paradigms, it must be stressed, are conceptual manifestations related to single

${ }^{26}$ Agamben, Signatura rerum. Sul metodo, 62. 
events, even when misleading analogies are present. For example, the political paradigm suits the case of Poland; for Bohemia, on the other hand, the confessional paradigm is intertwined with the philological one, which in turn gives rise to a metabolic chain that leads up to the vernacular song. The political and confessional paradigm suits Slovenia. In Croatia orality predominates and develops in two phases: a weaker phase of Homeric studies, and the phase of common language, which generated a political impact over a large portion of the southern Slavs.

The canon also deserves further reflection. As well as constantly resorting to music judged to be folk music in the name of simplicity (sic!), the folk collections of these countries assembled pieces that were reputed to be original in the nineteenth century. Even though they are exceptions, the contrafacta and the rewritings of art music prove the opposite, however. Besides, patriotism identifies its own raison d'être in the autochthonous tradition (true or alleged as the case may be), which in turn is related to language and ethnicity, even if, as Renan and Hobsbawm have pointed out, neither the one nor the other guarantees the unity of a country. If we follow Herder's ideas on poetry, the canon should be based on song types corresponding to the character of the peoples. Today, some two centuries later it is astonishing to learn that certain anthologies were considered as local expressions, even when they had little or nothing to do with the folklore. For example the church songs of the Slovenians or the hymns of the Czechs, who lacked an epic tradition comparable to that of the southern Slavs, were entrusted with this function - a fact that is today inexplicable, unless one were to substitute the term folksong with the more appropriate label of a song that was widely disseminated and transversal to all classes. Any piece of Trivialmusik, even of non-native origin, could be admitted to the category of folklore, given that it was the language and its wide dissemination that ensured the necessary popularity-quotient.

The paradigm, as we stated above, uses a vocabulary that is destined to be replaced, and the results that stem from the paradigm must invalidate the preceding regulatory framework, as is attested by the operas staged during the political events in Poland between 1793 and 1795. After the partition of the country by Prussia and Russia, both the Poles and the Russian occupiers identified the seeds of revolt in the singspiel Cud mniemany, czili Krakowiacy $i$ Górale (The Presumed Miracle or Cracovians and Highlanders, 1794) by the Czech composer Jan Stefani to a libretto by Wojciech Bogusławski. ${ }^{27}$ Even though the music's structure was by no means innovative, the sound of the krakowiak and the polonaise were sufficient to fire the spirits of the public. At another time those same features would have sounded like a diversion in the form of couleur locale. Instead, as a result of the dissolution of the Polish-Lithuanian Commonwealth, the nobility, and above all the bourgeoisie, were induced to project onto it the symbols of a love for one's fatherland. In this instance it is legitimate to speak of the constitution of a political paradigm, since it is a point of departure that the composers of the following generations could not ignore.

For an exact understanding of the Polish crisis we need to go back a few decades, to before the partition. The Sarmatism that cemented the unity of the Polish, Lithuanian and Ruthenian nobles, on the strength of a common descent from the ancient Sarmatians, was

${ }^{27}$ Źórawska-Witkowska, "People, Nation and Fatherland in Three Polish Operas", 41-58. 
subjected to severe criticism. Its basic values were in fact antithetical to the universalism of the Enlightenment. Sarmatism reappeared, however, in the nineteenth century after the dissolution of the country, and its reappearance was prepared by the Herderian ideas of Franciszek Salezy Jezierski, who upheld the individuality of every people as opposed to the sameness of the nobility in every country. For Jezierski the individuality of a nation, whatever its form of government, derived from the particular characters of the common people. In this regard, in the period between 1778 and 1794, there appeared on the stage thirty-five operas with rustic subjects, hence the denomination of opera wiejska (rustic opera). With the rise to power of Stanisław August Poniatowski the intermingling of popular language and the aulic writing of the Renaissance poet Jan Kochanowski was intensified. And as a result, long before Cud mniemany the repertoire became enriched with arias and dances inspired by the customs of the single regions of Poland. It was with the trauma of the lost independence, however, that the "natural song"28 of Bogusławski gave to the Poles a new awareness about the role of folklore as the expression of national feeling. On this subject some clarification on the dogmas of the Enlightenment in Poland is indispensible.

Unlike their French colleagues, the Poles were conservative and intent on safeguarding their local traditions. Given that the Lithuanians, Ruthenes and Masovians spoke languages and professed religions that were different from one another, a common foundation could be found in the use of a language super partes. Restraints were therefore imposed on literature with the aim of elevating Polish to the rank of national language. This policy had very distinct social implications, which are reflected in the contemporary novels. The main character in these novels speaks on behalf of everyone; he lives in the country; he is a small landowner committed to reforming agriculture, burdened by centuries of hardship. He detests the French-speaking nobility and does not consort with the country folk. For him the lifestyle of the lower classes is a cause of pride, but also acts as a stimulus to accomplish the redemption of the peasants from Feudalism. In this social vision, in which state and nation are the same thing, bourgeois themes of the Pamela type have no space and, for reasons that are easy to surmise, the Jew is sometimes a negative figure. ${ }^{29}$

While the political paradigm can be identified with rare precision in the singspiel of Stefani-Bogusławski, the situation in Bohemia, on the other hand, was very complicated, for there we see the stratification of three paradigms. In conjunction with the rise of an anti-German bourgeoisie, as a result of which Czech became the most spoken language around 1870, a secularised revision of Hussitism was also born. Thanks to his use of vernacular language a century before Luther, Jan Hus was presented as the upholder of the freedom of the Czech people. Obviously, a reinterpretation of this type ill fitted the Catholicism imposed on the country after the Thirty Years War. To remove the obstacle, considering that the Slovak protestants also made use of Czech as a vehicular language (see Jan Kollár, for example), the patriots found a good compromise in the celebration of a fourtheenth-century manuscript discovered at Dvůr Králové in 1817, along with the

${ }^{28}$ Id., "Popolo, nazione e patria nelle prime opera polacche (1778-1794)", in this volume, 31-43: 37.

${ }^{29}$ Rejman, "Les héros du canon littéraire des Lumières politiquement incorrect", 112-119. 
fragment from Zelená Hora of the eighth century (hence preceding Bohemia's conversion to Christianity) discovered in 1822 . To no avail were doubts on their authenticity cast by the authoritative Slavist Josef Dobrovský. On the strength of these paleoslavic texts Jan Palacký engaged in a personal battle to disseminate the icon of an antique Czech natio based on democracy. As regards music, the lack of the epos was offset by the tradition of the Protestant chorale, Jesuitical hymnography and the reassessment of the mythical singers Lumir and Záboj. The result of these dissimilar references was the reconstruction of a genuine and imaginary Middle Ages, to which Smetana contributed with his opera Libuše, which served to inaugurate the National Theatre in $1882 .{ }^{30}$

While the Czechs rediscovered Hussitism for purposes that were anything but religious, the Catholic Slovenes also engaged in the reassessment of the evangelical work of Primož Trubar. In the sixteenth century this enterprising Lutheran succeeded in imposing the language of the people, not only through the printing of sacred books and language primers, but also through the painstaking work of promoting literacy. However, the first collection of folk songs prepared by the Philharmonische Gesellschaft of Ljubljana in 1819 had no effect. What acted as a real cement was rather the church singing of the rural areas, into which the syntagmas of folklore had been incorporated. The scenario changed with the revolution of 1848. Not only in Ljubljana, but also in Graz and Trieste, the Slovenes gave a decisive impulse to national life by establishing the bésede, borrowed from the corresponding besedý of the Czechs. ${ }^{31}$ After 1861, along the coastal areas the experience of four-part choral music and national anthems accessible to amateurs, which began with the Ljubljanese Slovenska gerlica (The Slovene Turtledove) of 1848, became consolidated. The national opera, on the other hand, appeared at the end of the century with Benjamin Ipavec's Teharski plemič (The Noblemen of Teharje, 1892), Viktor Parma's Urh, grof celjski (Ulrich, Count of Cilli, 1894) and Anton Foerster's Gorenjski slavček (The Nightingale of Upper Carniola, 1896), after though without causing much of a stir.

Paradigms are born and develop by autogenesis. Ever since the times of Herder the poems of Ossian were the object of drawn-out polemics, though this in no way diminished their fame, for they were rapidly translated into Italian, German, Czech and Polish. To no avail were the accusations of forgery or, as Hugh Trevor-Roper claimed, of a revisitation of a legacy that had been transported to Scotland by Irish bards and sung by the "remnants". ${ }^{32}$ The Gaelic texts exerted an influence only in the narrow circles of élite culture. The many versions in the various languages of Europe, among the first those by Michael Denis and Melchiorre Cesarotti, failed to produce tangible effects, if we exclude the Ossians Gesänge by Franz Schubert, the operas Comala by Thomas Busby (1800),

${ }^{30}$ Ottlová, Pospíšil, “Zum Rezeptiongeschichtlichen Hintergrund der tschechischen Nationaloper”, 23-35.

${ }^{31}$ Cigoj Krstulović, "Uvod v glasbeno delo čitalnic na Slovenskem do ustanovitve Glasbene Matice (1848-1872)", 61-74; Klemenčič, "The Contribution of Music to Slovenian National Awakening", 513-530. On Trieste and the joined hinterland: Rojc, Cultura musicale degli sloveni a Trieste: dal 1848 all'avvento del fascismo.

32 Trevor-Roper, "The Invention of Tradition: The Highland Tradition of Scotland", 16: "In the eighteenth century, the Western Islands were still essentially an Irish overflow, and the Gaelic language spoken there was regularly described, in the eighteenth century, as Irish.” 
Ossian by Jean-François Lesuer (1804), Fingallo e Comala by Stefano Pavesi (1805), Colmal by Peter von Winter (1809), and the later symphonic works such as Die Hebriden (1829) by Felix Mendelssohn..$^{33}$ Nor did all of this take place among the Slavic populations, in spite of the existence of a version translated into Czech by František Palacký (1817). Nonetheless, these songs in Earse helped to generate a new interest in oral sources and the only consequence worthy of note was the revival of the classical epos in the light of Ossian, who was renamed the "Nordic Homer". In fact Homer acted as a cue for Giulio Bajamonti, who set out to compare the Iliad to the pjesme of the Morlack guslari, the bards believed to be the survivors of the ancient civilisation of the Balkanic Slavs. ${ }^{34}$ The Illyrian movement that followed, however, did not avail itself of similar arguments, but instead boosted the musical repertoire by including any piece of demotic origin, provided that it was written in neoštokavjan, the potentially transnational language spoken in certain areas of Croatia, in Bosnia, Serbia and Montenegro.

According to Foucault's perspective, the travel literature, or the research of Andrija Kačić-Miošić on the folk poetry, are not the causes that create a cult of the nation. We must wait for the interposition of the critical factor, in other words the fall of the Venetian Republic (1797) and Bajamonti's consequent reflections on the subject. In his Morlacchismo di Omero (1797) Bajamonti sketches a monogenetic portrait of the southern Slavs, drawing attention to the narrative analogies between classical and Morlack epic as reassessed from an anthropological perspective. ${ }^{35}$ Croatian Illyrism, indifferent to the pseudohistorical claims of Morlackism and professing less pretentious viewpoints, advocated a phenomenon that used language as the discriminating factor. ${ }^{36}$ In order to resolve the Balkan puzzle the paradigm of orality merged with both the revival of the decasyllables sung by heart by the guslari and the study of the ancient literature of Dubrovnik belonging to the same linguistic group.

The first fruits of Illyrism can be observed in Ljubav i zloba (Love and Malice) of 1846, an opera by Vatroslav Lisinski (alias Ignaz Fuchs) that is partially influenced by Gaetano Donizetti. One should not overlook, however, the experiences that lay behind this achievement, which can be traced back to the operatic repertoire of the German companies and, to a lesser extent, those of the Italians. ${ }^{37}$ Equally decisive was Lisinski's choral output. The works by this amateur composer met with considerable success between 1841 and 1845, i.e. during the period when the pro-Hungarian party opposed the Croat Ljudevit Gaj's proposal of a language reform, which implicitly anticipated the birth of a federation of states to the detriment of Hungary. ${ }^{38}$ The Yugoslav-oriented project of Gaj influenced Lisinski, who composed the overture Slavenka (1848) in Prague, the meeting point of Central European Pan-Slavism.

33 Dahlhaus, Nineteenth Century Music, 21, 166.

${ }^{34}$ Cavallini, "Ossian, Omero e il bardo morlacco", 259-288.

${ }^{35}$ Bajamonti, "Il morlacchismo di Omero", 77-98.

${ }^{36}$ Tuksar, "On Some Concepts of Panslavism and Illyrism", 79-102.

${ }^{37}$ Katalinić, "Paralelni svjetovi ili dvostruki identitet?", 323-340.

${ }^{38}$ Palić-Jelavić, “Z Zborsko stvaralaštvo Vatroslava Lisinskog”, 289-306. 


\section{Nationalism vs. Cosmopolitism?}

In the context of the relations between dominant and subservient cultures, the need to give a formal definition of the musics circulating in Mitteleuropa could be fulfilled by resorting to the categories of subordination, adaptation and autonomy. But in actual fact any strict recourse to these categories, which imply a high degree of simplification, is untenable in view of the intermingling of styles.

Concerning the emancipation from foreign models, a precious source is constituted by the suggestions for imposing a national physiognomy on opera, a genre in which the national setting was comprehensible to any type of audience. The instructions given by the Czech Otakar Hostinský and the Croat Franjo Kuhač, either to reject Wagner's Musikdrama or to accept it with reservations, are irrefutable proof of this tendency. From another viewpoint, any classification becomes insubstantial when dealing with the widely disseminated musics that are considered as autochthonous only on account of their language, even when they show traces of foreign influences. Furthermore, many folk collections cannot be assessed in aesthetic terms, because their aim was to consolidate political claims. But even at higher level, in situations where a technical assessment devoid of ideological implications can be made, it is not easy to constrain the scores within strict boundaries delimitating the degree of imitation or creative freedom.

Equally inadmissible, finally, is the opposition national vs. cosmopolitan, since they were two components destined to coexist for a long time, as two halves of the same culture. In order to become acceptable as a school, it is claimed that the art music in Poland, Bohemia, Slovenia and Croatia, all countries involved in national struggles, would have had to reject the 'exogenous' models. Obviously this is a prejudice that can be easily disproved, even if it stubbornly refuses to die in musicological circles, bewitched by the modernity of a handful of composers active in semi-feudal Russia. Smetana, Dvořák, Zajc and Parma (two Czechs, a Croat and a Slovenian) were capable of following the teachings of Liszt, Brahms, Verdi and Mascagni respectively, but at the same time and with equal skill they knew how to transfigure unusual formulas when resorting to the national-folk sources. Hence we should accept that their culture, which was equally distributed between German, Italian and national tendencies, was based on a sort of tri-lingualism which is difficult to understand after the establishment of the national historiographies, but which at the time created no serious conflicts. Even if localism or nationalism serve to label the artistic expressions of communities that were dissatisfied, but basically faithful to the Habsburg Empire until 1918, and if cosmopolitism refers to the performances of music from the centres driving the consolidated cultures, that does not mean that there was an automatic rupture. Let us clarify with an example.

For the Slavophone and Germanophone bourgeoisies, right down to the early twentieth century, it was natural to consider Italian opera as if it were a supranational product, even when the requirement was to translate the texts of foreign authors and compose to librettos in the mother-tongue. In accordance with a deeply entrenched convention, the genre of opera was Italian, and in part French, and appreciated in equal measure by audiences in Warsaw, Vienna, Prague, Ljubljana and Zagreb. Rather than an antithesis between nationalism and cosmopolitism, it would be more proper to speak of symbiosis 
or parallel lives. The spread of musics born elsewhere, yet made their own at the level of both reception and composition, was a practice comparable to the use of German as Umgangssprache. In my opinion cosmopolitism is conceivable in an equal, and not only contrary, relation to patriotism and to its nationalistic deviations. And in fact, Italian and French opera, like the symphonic and chamber music of the German authors, were embraced by all the Slavic peoples, who identified themselves in those repertoires, while remaining aware of their ethnic and linguistic diversity. One of the sins of twentiethcentury musicology, which again was divided between east and west, was to treat the relationship between the domestic currents and the cosmopolitan art as conflictual and not dialectic. In 1978, when the boundaries became more fragile and the weakness of terms such as Eastern Europe became evident, Dragotin Cvetko stigmatized this incongruity: "Even from what we already know it is obvious that despite some crucial differences the two kinds of music have so much in common and are so closely related to each other that they cannot be treated separately." ${ }^{39}$

As the above clarifications suggest, what is needed is a correct methodological perspective on the usage of the adjective folk. That advanced by Matthew Gelbart in certain ways can be useful. ${ }^{40}$ For the American musicologist, art music and folk music are constructions conceived as categories outside time, and in that respect similar to the "invented traditions" of Hobsbawm. ${ }^{41}$ In spite of their close connection, they have been examined in terms of reciprocal exclusion. It was possible for this to happen when an ageold way of thinking, based on the functions of music, was supplanted by the concept of creativity and obsessive search for origins. ${ }^{42}$ As a result, the presence of features extracted from folklore and re-inserted into art music, or contrarily, the popular success of melodies taken from operas, have complicated our interpretation of the function carried out by the various types of music that are labelled as folk (traditional music, music composed for the people, church songs, hymns and choruses written by composers, opera arias). Within the evolution of art music in the Slavic countries of Mitteleuropa there were continual interactions between utility and autonomy, which oblige us to examine carefully both the modes of reception and the technical quality of the scores. Otherwise it would be difficult to explain the success of any compositional genre, symphonic works included, as

${ }^{39}$ Cvetko, "The Present Relationship between the Historiography of Music in Eastern and Western Europe", 159.

${ }^{40}$ Gelbart, The Invention of Folk Music and Art Music: Emerging Categories from Ossian to Wagner.

${ }^{41}$ Ibid., 6: "Folk music and art music, being recent constructions that have portrayed themselves as timeless categories, share much with the idea of "invented traditions"; 7: "To understand fully the persistence and influence of these categories, we must [...] recognize [...] the specific historical interdependence of folk and art as a binary, dialectical pairing. These signifiers have gained their referents through contrast and opposition to each other: throughout their history, the fact that folk music and art music have functioned in dialogue with each other has rendered their force exclusive rather than inclusive".

${ }^{42}$ Ibid., cover: "Whereas earlier ways of classifying music were based on its different functions, for the past two hundred years we have been obsessed with creativity and musical origins, and classify music along these lines". 
long as it referred to the history of the homeland. ${ }^{43}$ When many composers attempted to forge an alternative style to that of the dominant cultures, the response of the public was always positive, even when the results were not of high quality, for its perception was guided by identitary feelings and not by critical judgement. Some composers achieved this objective with decades of delay compared to Russia or Bohemia. The results were no less extraordinary, especially when were they introduced, with skill and refinement, the intermixing of modal and polytonal systems derived from the true ethnic grammar. ${ }^{44}$

\section{Conclusions}

The national paradigm, when it takes root in the conscience of groups, is a contract of consent that defines and produces the rites of self-representation. In the last two centuries the musics associated with the folk canon have been walking a fine line between the concepts - understood as unchanging elements in an immobile universe - of language, ethnicity and tradition. And even if one detects an adaptation to the dynamics of history in these concepts, the paradigm from which they originated exists regardless. It stands like a breaking point within the system and does not allow one to predict the form of the future outcomes. Identity, however, is never the outcome of neutral theories, but a repositioning of the paradigm aimed to exert an influence on practice. The canon, which is passed off as natural, claims to convey a unanimous accord, whereas the arbitrary alliance of ideology with reality is always deceptive.

${ }^{43}$ Bergamo, "Umetniški značaj proti smotru: med polariziranjem in harmoniziranjem”, 211-228. The author dwells on the three different ways in which, in the modern age, a conflictual polarisation occurred between (instrumental) pure music and (operatic and otherwise) vocal music, then within the context of instrumental music only, between absolute music and programme music, and from the 1920s between autonomous music and functional music. Her reflections are founded on the studies of Carl Dahlhaus and the entries on Absolute Musik, Autonome Musik, Funktionale Musik, written by Albert von Massow for the Handwörterbuch der musikalischen Terminologie, Auslieferung 22, hrsg. von Hans Heinrich Eggebrecht, Stuttgart, Franz Steiner, 1994. Cf. also Cigoj Krstulović, "Glasba za rabo kot družbenozgodovinski pojav v drugi polovici 19. stoletja na Slovenskem", 65-76. The author analyses the different roles of the so-called "utilitarian" repertoires, from the birth of the national awakening in 1848 until the end of the century, when they gradually lost their initial functionality and became music for "domestic use".

${ }^{44}$ Béla Bartók's œuvre on the peasant tradition of Hungary is defined by David Cooper as a nationalistic reaction to the gipsy music: Cooper, "Béla Bartók and the Question of Race Purity in Music", 16-32. 


\section{Bibliography}

Aristotle. De sophisticis elenchis, edited by William David Ross, Oxford: OUP, 1958. Agamben, Giorgio. Signatura rerum. Sul metodo. Torino: Bollati Boringhieri, 2008. Agnelli, Arduino. La genesi dell'idea di Mitteleuropa. Milano: Giuffrè, 1971.

Anderson, Benedict. Imagined Communities. Reflections on the Origin and Spread of Nationalism, 83-113. London - New York: Verso, 1991.

Bajamonti, Giulio. "Il morlacchismo di Omero". Nuovo Giornale Enciclopedico d'Italia 10 (1797): 77-98.

Bergamo, Marija. "Umetniški značaj proti smotru: med polariziranjem in harmoniziranjem" [Artistic Character versus Purpose: Between Musical Autonomy and Harmonization]. De Musica disserenda 2, no. 2 (2006): 211-228.

Bibó, István. Misère des petits États d'Europe de l'Est, edited by György Kassai. Paris: Albin Michel, 1993.

Cavallini, Ivano. "Ossian, Omero e il bardo morlacco. Su Giulio Bajamonti e la scoperta degli antichi slavi”. In Musicologie sans frontières. Svečani zbornik za Stanislava Tuksara. Essays in Honour of Stanislava Tuksara, edited by Ivano Cavallini and Harry White, 259-288. Zagreb: Hrvatsko muzikološko društvo, 2010.

Cesa, Claudio. "Popolo, nazione e stato nel romanticismo tedesco". In Figure del romanticismo, edited by Margherita Cottone, 145-166. Venezia: Marsilio, 1987.

Cigoj Krstulović, Nataša. "Uvod v glasbeno delo čitalnic na Slovenskem do ustanovitve Glasbene Matice (1848-1872)” [Musical Activity of Reading Societies in Slovenia until the Founding of Musical Centre (1848-1872)]. Muzikološki zbornik 32 (1996): 61-74. "Glasba za rabo kot družbenozgodovinski pojav v drugi polovici 19. stoletja na Slovenskem" [Utilitarian Music as a Socio-Historical Phenomenon in the Slovenian Territory in the Second Half of the Nineteenth Century]. De musica disserenda 3, no. 1 (2007): 65-76.

Cooper, David. "Béla Bartók and the Question of Race Purity in Music". In Musical Constructions of Nationalism: Essays in the History and Ideology of European Musical Culture 1800-1945, edited by Harry White and Michael Murphy, 16-32. Cork: Cork University Press, 2001.

Cvetko, Dragotin. "The Present Relationship between the Historiography of Music in Eastern and Western Europe". The International Review of the Aesthetics and Sociology of Music 9, no. 2 (1978): 151-160.

V prostoru in času. Spomini. [In Space and Time. Memories]. Ljubljana:

Slovenska matica, 1995.

Dahlhaus, Carl. Nineteenth Century Music. Translated by John Bradford Robinson. Berkeley and Los Angeles: University of California Press, 1989.

Fortuna, Sara. "Note su oblio, paradigma e discipline linguistiche a partire da Signatura rerum. Sul metodo di Giorgio Agamben". Studi Linguistici e Filologici Online 8, no. 2 (2005): 205-222.

Foucault, Michel. Les mots et les choses. Une archéologie des sciences humaines. Paris: Gallimard, 1966.

The Archaeology of Knowledge and the Discourse on Language. Translated by Alan Mark Sheridan Smith. New York: Pantheon Books, 1972. 
The Order of Things: An Archaeology of the Human Sciences. Translated by Don Ihde. New York: Vintage Books, 1994.

Gelbart, Matthew. The Invention of Folk Music and Art Music: Emerging Categories from Ossian to Wagner. New York: Cambridge University Press, 2007.

Gellner, Ernest. Nations and Nationalism. Ithaca: New York Cornell University Press, 1983.

Hobsbawm, Eric. Nations and Nationalism since 1780. Program, Myth, Reality. New York: Cambridge University Press, 1992.

Katalinić, Vjera. "Paralelni svjetovi ili dvostruki identitet? Strane operne družine i nacionalna glazbena nastojanja u Zagrebu u prvoj polovici 19. stoljeća” [Parallel Worlds or Double Identity? Foreign Opera Companies and National Musical Strivings in Zagreb in the First Half of the Nineteenth Century]. In Musicologie sans frontières. Muzikologija brez granica. Svečani zbornik za Stanislava Tuksara, edited by Ivano Cavallini and Harry White, 323-340. Zagreb: Hrvatsko muzikološko društvo, 2010.

Kindl, Ulrike. "Im namen des deutschen Volkes: in nome del popolo tedesco. Uso e accezione storica dei concetti di Volk e Nation nella lingua tedesca." In I linguaggi e la storia, edited by Antonio Trampus and Ulrike Kindl, 299-333. Bologna: Il Mulino, 2004.

Klemenčič, Ivan. "The Contribution of Music to Slovenian National Awakening. The Role of Reading Rooms between Trieste, Ljubljana and Maribor (1848-1872)". Musica e Storia 12, no 2 (2004): 513-530.

Kundera, Milan. “Un occident kidnappé ou la tragédie de l'Europe centrale.” Le Débat, 5, no. 27 (1983): 3-23. Published electronically. doi: 10.3917/deba.027.0003

"The Tragedy of Central Europe." The New York Review of Books 31, no. 7 (1984): 33-38.

Le Rider, Jacques. La Mitteleuropa. Paris: PUF, 1994.

Magris, Claudio. Il mito asburgico nella letteratura austriaca moderna. Torino: Einaudi, 1966.

Ottlová, Marta and Pospíšil, Milan. “Zum Rezeptiongeschichtlichen Hintergrund der tschechischen Nationaloper". De Musica disserenda 3, no. 1 (2007): 23-35.

Palić-Jelavić, Rozina. “Zborsko stvaralaštvo Vatroslava Lisinskog u ozračju povijesnik, društvenopolitičkih, ideologijških i kulturnih krajolika" [Choral Works by Vatroslav Lisinski in the Context of Historical, Socio-Political, Ideological and Cultural Landscapes]. In Musicologie sans frontières, Muzikologija brez granica. Svečani zbornik za Stanislava Tuksara, edited by Ivano Cavallini and Harry White, 289-306. Zagreb: Hrvatsko muzikološko društvo, 2010.

Radole, Giuseppe. Le scuole musicali a Trieste e il Conservatorio "Giuseppe Tartini". Trieste: Svevo, 1992.

Rejman, Zofia. "Les héros du canon littéraire des Lumières politiquement incorrect". In Culture et identité en Europe centrale: canons littéraires et visions de l'histoire, edited by Michel Masłowski, Didier Francfort, Paul Gradvohl with the collaboration of Anne Nercessian and Clara Royer, 112-119. Paris: Institut d'Études Slaves, Brno: Mazarykova Univerzita, 2011.

Rojc, Aleksander. Cultura musicale degli sloveni a Trieste: dal 1848 all'avvento del fascismo. Trieste: Editoriale Stampa Triestina, 1978.

Seton-Watson, Hugh. Nations and States: An Enquiry into the Origins of Nations and the Politics of Nationalism. Boulder: Colo Westview Press, 1977. 
Symaniec, Virginie. La construction idéologique slave orientale. Langues, races et nations dans la Russie du XIXe siècle. Paris: Pétra, 2012.

Ther, Philipp. "The Czechs as Cultural Role Models: Cultural Transfer from Bohemia to South-eastern Europe in the Late Habsburg Empire". In Musical Theatre as High Culture? The Cultural Discourse on Opera and Operetta in the $19^{\text {th }}$ Century, edited by Vjera Katalinić, Stanislav Tuksar and Harry White, 49-61. Zagreb: Hrvatsko muzikološko društvo, 2011.

Trevor-Roper, Hugh. "The Invention of Tradition: The Highland Tradition of Scotland." In The Invention of Tradition, edited by Eric Hobsbawm and Terence Ranger, 15-41. New York: Cambridge University Press, 1983.

Tuksar, Stanislav. "On Some Concepts of Panslavism and Illyrism in South Slavic Peoples, and the Idea of National Music in Croatia during the $19^{\text {th }}$ Century". In Nation and/or Homeland. Identity in Nineteenth Century Music and Literature between Central and Mediterranean Europe, edited by Ivano Cavallini, 79-102. Milano: Mimesis, 2012. Vodopivec, Peter. "Mitteleuropa - Mythos oder wirklichkeit?". Muzikološki zbornik 40, no. 1-2 (2004): 29-42.

Weiss, Jernej. Čě̌ki glasbeniki v 19. in na začetku 20. stoletja na Slovenskem [Czech Musicians in the Nineteenth and Early Twentieth Centuries in Slovenia]. Maribor: Litera, 2013.

Żórawska-Witkowska, Alina. "Bömischer Musiker in Warschau unter der Regierung von Stanislaus August Poniatowki (1764-1795)." In Musicologie sans frontières, Muzikologija brez granica. Svečani zbornik za Stanislava Tuksara, edited by Ivano Cavallini and Harry White, 242-257. Zagreb: Hrvatsko muzikološko društvo, 2010. "People, Nation and Fatherland in Three Polish Operas: Cud Mniemany, czili Krakowiacy i Górale (1794), Jadwiga Królowa Polska (1814), Król Łokietek, albo Wiślicanki (1818)." In Nation and/or Homeland. Identity in $19^{\text {th }}$ Century Music and Literature between Central and Mediterranean Europe, edited by Ivano Cavallini, 41-58. Milano: Mimesis, 2012.

"Popolo, nazione e patria nelle prime opera polacche (1778-1794)". De musica disserenda 12, no. 1 (2016): 31-43.

Zupančič, Maruša. "V iskanju lastne identitete: češki violinist kot glavni tvorci violinizma na Slovenskem". [In Search of Its True Identity: Czech Violinists as the Main Creators of Violinism in Slovenian Lands]. De musica disserenda 4, no. 2 (2008): 105-132. 


\section{KULTURNE PARADIGME IN POPULARNI KANON: DISKURZ O NARODU V SLOVANSKI SREDNJEEVROPSKI GLASBI 19. STOLETJA}

\section{Povzetek}

Razprava se osredotoča na Srednjo Evropo kot geografski pojem in na Srednjo Evropo (Mitteleuropa) kot kulturni pojem. Pojasniti skuša vlogo različnih vrst glasbe v slovanskih deželah v 19. stoletju, v času po narodnih preporodih na Poljskem, Češkem, Slovenskem in Hrvaškem, ko je postalo vprašanje avtonomije posebno pomembno. V teh razmerah so imeli vodilno vlogo češki glasbeniki - ti so se naseljevali v različnih pokrajinah omenjenih dežel, ki so v političnem pogledu pripadale Prusiji, Rusiji in habsburški monarhiji. Prispevali so k nastanku preporodnih gibanj in z njimi povezanega odkritja ljudskega vključno s starimi slovstvenimi izročili. To je služilo kot osnova za idejo o novi umetni glasbi. Prizadevanja za uveljavitev lastne identitete so - za razliko od uporabe nemških modelov za instrumentalno glasbo in »nadnacionalne« italijanske opere - pospešila nastajanje partitur, ki so poudarjale bodisi avtentične ali pa le domnevne ljudske vzorce. Čeprav je bil poziv k ustanovitvi zveze neodvisnih držav eden od vzrokov za razpad avstrijskega dinastičnega univerzalizma, ni mogel preprečiti spontanih interakcij med glasbenimi kulturami Nemcev in Slovanov. Te kulture so rasle skupaj, in kot je mogoče videti iz življenjepisov Čeha Antonína Dvořáka, Hrvata Ivana Zajca in Slovenca Viktorja Parme, so se medsebojno oplajale. V tej zvezi so lahko kategorije podrejenosti, prirejenosti in avtonomnosti nadomeščene s primernejši izrazi, kot sta denimo uporabna in avtonomna glasba, saj je v slovanski Srednji Evropi (Mitteleuropa) nacionalno obstajalo hkrati s kozmopolitskim. Nacionalna identiteta, tema, ki je bila skupna tako poljskemu, češkemu, slovenskemu in hrvaškemu meščanstvu, se lahko obravnava s konceptoma paradigme in kanona. Kot meni Giorgio Agamben v svojem Foucaultovi filozofiji zavezanem delu Signatura rerum (2008), je paradigma element, ki ima zmožnost, da se razvija. Z zgodovinskega stališča je tisti konfliktni dejavnik, ki kliče k reorganizaciji predhodnega reda. $\mathrm{Z}$ drugimi besedami deluje paradigma kot tisti otipljivi in statični dejavnik, iz katerega lahko v zgodovinskem sosledju izide nov proces. Njena vrednost, se pravi gonilna sila njenega impulza, je razpoznavna le v zvezi s kanonom. Kanon je tako rezultat obsežnega toposa kot so ljudska pesem in popularna glasba, ki sta bili v 19. stoletju močno prežeti z jezikom, vero, narodnostjo in bodisi pristnimi ali umetnimi resničnimi ali izmišljenimi tradicijami. Gledano v tej luči je delitev Poljske v letih 1793-95 privedla do politične paradigme; oživitev husitskega gibanja je na Češkem pripravila pot verski paradigmi, ki je bila nadalje vzrok za porast pesmi v češčini; na Slovenskem sta bili ugodni politična in verska paradigma; na Hrvaškem pa je paradigma ustnega izročila v obliki epskega pripovedništva prevladala kot vir skupnega jezika v smislu enotnosti južnih Slovanov. Kljub njihovi raznolikosti so te paradigme razvile popularni kanon, ki je kot oblika samo-reprezentacije obvladoval ljudsko in umetno glasbo tudi po prvi svetovni vojni. 